\title{
Effect of Grains Differing in Expected Ruminal Fermentability on the Productivity of Lactating Dairy Cows
}

\author{
C. Silveira, ${ }^{*}$ M. Oba, ${ }^{* 1}$ K. A. Beauchemin, $\dagger$ and J. Helm¥ \\ *Department of Agricultural, Food and Nutritional Science, University of Alberta, Edmonton, Alberta, T6G 2P5, Canada \\ †Agriculture and Agri-Food Canada, Lethbridge, Alberta, T1J 4B1, Canada \\ $\ddagger$ Alberta Agriculture Food and Rural Development, Lacombe, Alberta, T4L 1W8, Canada
}

\section{ABSTRACT}

The objective of the study was to evaluate the effect of barley and corn grains differing in expected fermentability in the rumen on dry matter intake (DMI) and productivity of lactating dairy cows. Twenty-two multiparous and 9 primiparous lactating Holstein cows $(94 \pm 29 \mathrm{~d}$ in milk; mean $\pm \mathrm{SD})$ were used in a $3 \times 3$ Latin square design with 21-d periods. Experimental diets contained approximately $40 \%$ of dietary dry matter as steam-rolled barley, using a lot of cultivar Dillon or cultivar Xena, or a corn mixture $(\mathrm{CM})$ containing $87.5 \%$ dry ground corn, $11.4 \%$ beet pulp, and $1.1 \%$ urea (dry matter basis). Starch concentration of the grain sources was 50.0, 58.7, and $60.4 \%$ and in vitro 6 -h starch digestibility was $73.5,78.0$, and $71.0 \%$, respectively, for Dillon, Xena, and CM. All diets were formulated to contain $19.4 \%$ crude protein and $25.3 \%$ forage neutral detergent fiber. Dry matter intake (23.6 vs. $21.6 \mathrm{~kg} / \mathrm{d}$ ) and yields of milk (40.4 vs. $37.4 \mathrm{~kg} / \mathrm{d})$, milk protein $(1.20$ vs. $1.12 \mathrm{~kg} / \mathrm{d}$ ), and milk lactose (1.85 vs. $1.74 \mathrm{~kg} / \mathrm{d}$ ) were higher for cows fed CM than for cows fed barley. Although DMI was similar for cows fed Xena and Dillon (21.9 vs. $21.4 \mathrm{~kg} / \mathrm{d})$, cows fed Xena had higher yields of milk (38.5 vs. $36.2 \mathrm{~kg} / \mathrm{d}$ ), milk protein ( $1.18 \mathrm{vs.} 1.07 \mathrm{~kg} /$ d), and milk lactose (1.80 vs. $1.69 \mathrm{~kg} / \mathrm{d}$ ) than cows fed Dillon. However, milk fat concentration tended to be higher (3.47 vs. 3.23\%) for cows fed Dillon than Xena. Plasma glucose and nonesterified fatty acid concentrations were not affected by treatment, but plasma insulin concentration was higher for cows fed Xena compared with those fed Dillon (8.50 vs. $5.91 \mu \mathrm{IU} / \mathrm{mL}$ ). Greater milk production for cows fed CM can be attributed to greater DMI. Feeding barley that was lower in starch concentration and ruminal starch fermentability (Dillon) did not increase DMI compared with feeding barley that was higher in starch concentration and ruminal starch fermentability (Xena). Reducing ruminal starch

Received October 6, 2006.

Accepted February 2, 2007.

${ }^{1}$ Corresponding author: masahito.oba@ualberta.ca degradation of barley grain may not improve the productivity of lactating dairy cows.

Key words: barley, starch digestibility, milk production, dairy cow

\section{INTRODUCTION}

Barley is the primary grain fed to ruminants in the northwestern United States, western Canada, and Europe. Barley is highly degradable in the rumen and often causes production of excess fermentation acid, decreasing rumen $\mathrm{pH}$ (McCarthy et al., 1989; Robinson and Kennelly, 1989; Nocek and Tamminga, 1991). Overton et al. (1995) fed dairy cows diets containing 5 different ratios of starch from ground shelled corn and steam-rolled barley and found that DMI and milk yield decreased as the ratio of starch from steam-rolled barley increased. A rapid rate of carbohydrate degradation is associated with sharp reductions in DMI and milk production (McCarthy et al., 1989; Aldrich et al., 1993; Mitzner et al., 1994). Thus, the decreased DMI and productivity for cows fed barley grain compared with corn grain might be caused in part by rapid fermentation in the rumen.

A significant variation exists in the chemical composition of barley grain. Barley grain has been reported to vary from 7.5 to $15 \%$ in CP concentration (LaFrance and Watts, 1986), from 17 to $32 \%$ in NDF concentration (Ovenell-Roy et al., 1998b), and from 45.9 to $62.8 \%$ in starch concentration (Ovenell-Roy et al., 1998b). Furthermore, Khorasani et al. (2000) reported that the rate of in situ DM degradation varied from 20.0 to $64.4 \% / \mathrm{h}$ among 60 lots of barley grain cultivars. Yu et al. (2004) showed distinctive differences in chemical and structural endosperm matrix makeup between the barley cultivars Valier and Harrington using infrared microspectroscopy, and these differences are expected to affect the rate of starch degradation in the rumen.

Barley grain differing in chemical or physical characteristics is expected to affect the productivity of animals. For example, barley cultivars varying in nutrient composition affect the feed efficiency of beef cattle (Boss 
Table 1. Nutrient composition of the grains used to formulate the experimental $\operatorname{diets}^{1}$

\begin{tabular}{lrrr}
\hline Item & CM & Dillon & Xena \\
\hline Test weight, kg/hL & - & 61.5 & 75.3 \\
DM, \% & 95.1 & 89.6 & 87.7 \\
CP, \% of DM & 12.8 & 10.1 & 12.6 \\
Soluble protein, \% CP & 2.2 & 2.0 & 2.3 \\
ADF, \% of DM & 3.7 & 8.1 & 3.7 \\
NDF, \% of DM & 14.3 & 27.0 & 19.0 \\
Ether extract, \% of DM & 2.8 & 2.2 & 2.0 \\
Ash, \% of DM & 1.6 & 2.9 & 2.8 \\
Starch, \% of DM & 60.4 & 50.0 & 58.7 \\
In vitro 6-h starch digestibility, \% starch & 71.1 & 73.5 & 78.0 \\
\hline
\end{tabular}

${ }^{1} \mathrm{CM}=$ corn mix containing $87.5 \%$ dry ground corn, $11.4 \%$ beet pulp, and $1.1 \%$ urea (DM basis); Dillon = steam-rolled barley, cultivar Dillon; Xena = steam-rolled barley, cultivar Xena.

and Bowman, 1996; Zinn et al., 1996). However, little research has been conducted to evaluate the effects of barley grain cultivars on the productivity of lactating dairy cows. We hypothesized that barley grain varying in physical and chemical characteristics would affect the productivity of lactating dairy cows. Further, because excess fermentation in the rumen often decreases DMI (Allen, 2000), we also hypothesized that DMI and milk production of cows fed a less fermentable source of barley would be similar to cows fed corn. Therefore, the objective of this study was to evaluate the effect of grains differing in starch content and expected fermentability in the rumen on DMI and productivity of lactating dairy cows.

\section{MATERIALS AND METHODS}

\section{Cows, Diets, and Treatments}

Twenty-two multiparous and 9 primiparous Holsteins cows in early to midlactation $(94 \pm 29 \mathrm{DIM} ; \bar{X} \pm$ SD) from the University of Alberta Dairy Research and Technology Centre were randomly assigned to a treatment sequence within a $3 \times 3$ Latin square balanced for carryover effects. At the beginning of the experiment, cows averaged $626 \pm 84 \mathrm{~kg}$ and BCS was $3.0 \pm$ 0.35 . Treatment periods were $21 \mathrm{~d}$, with the final $7 \mathrm{~d}$ used to collect samples and data. Cows were cared for according to guidelines of the Canadian Council on Animal Care (Institutional Animal Use Approval Number: 2005-13C).

Two 15-t lots of barley grain, cultivars Xena and Dillon, were obtained from a local grain company. These 2 lots were selected because of the distinctive differences in their physical and chemical characteristics (Table 1). A corn mixture (CM) containing $87.5 \%$ dry ground corn, $11.4 \%$ beet pulp, and $1.1 \%$ urea on a DM basis was prepared. The CM was designed to approximate the $\mathrm{CP}$ and starch concentrations of barley grains.
Table 2. Ingredients and nutrient composition of experimental diets containing either a corn mixture $(\mathrm{CM})^{1}$ or steam-rolled barley, cultivar Dillon or cultivar Xena (\% of DM)

\begin{tabular}{|c|c|c|c|}
\hline \multirow[b]{2}{*}{ Item } & \multirow[b]{2}{*}{$\mathrm{CM}$} & \multicolumn{2}{|c|}{ Barley } \\
\hline & & Dillon & Xena \\
\hline \multicolumn{4}{|l|}{ Ingredient } \\
\hline Barley silage & 26.6 & 27.3 & 27.4 \\
\hline Alfalfa hay & 15.8 & 16.1 & 16.2 \\
\hline Basal concentrate $\operatorname{mix}^{2}$ & 17.0 & 17.5 & 17.5 \\
\hline $\mathrm{CM}$ & 40.6 & - & - \\
\hline Dillon, steam-rolled & - & 39.1 & - \\
\hline Xena, steam-rolled & - & - & 38.9 \\
\hline \multicolumn{4}{|l|}{ Nutrient composition } \\
\hline Forage NDF & 25.1 & 25.3 & 25.5 \\
\hline NDF & 33.0 & 39.3 & 37.5 \\
\hline $\mathrm{CP}$ & 19.4 & 19.4 & 19.6 \\
\hline Starch & 28.7 & 22.3 & 25.3 \\
\hline Ether extract & 3.0 & 2.6 & 2.3 \\
\hline
\end{tabular}

${ }^{1} \mathrm{CM}=$ corn mixture containing $87.5 \%$ dry ground corn, $11.4 \%$ beet pulp, and $1.1 \%$ urea (DM basis),

${ }^{2}$ Basal concentrate mix contained $10 \%$ beet pulp, $10 \%$ Megalac (Church and Dwight, Princeton, NJ), 0.5\% vegetable oil, $17.5 \%$ fish meal, $14 \%$ corn meal, $22 \%$ canola meal, $3.8 \%$ limestone, $1.2 \%$ magnesium oxide, $1.9 \%$ sodium bicarbonate, $7.7 \%$ calcium phosphate, and $11.4 \%$ premix of microminerals and vitamins (DM basis).

Starch concentration was 50.0, 58.7, and $60.4 \%$ and 6$\mathrm{h}$ in vitro starch digestibility was $73.5,78.0$, and $71.0 \%$, respectively, for Dillon, Xena, and CM. Although actual ruminal starch digestion of grains was not measured in this study, it was expected to differ because of the differences in starch concentration and 6-h in vitro starch digestibility. Furthermore, a subsequent companion study with ruminally and intestinally cannulated cows confirmed these differences in fermentability (Silveira et al., 2007). Three experimental diets were formulated to contain approximately equal amounts of steam-rolled barley, using either Dillon or Xena, or CM (Table 2). All diets were designed to meet or exceed requirements for $\mathrm{CP}$, RUP, vitamins, and minerals (NRC, 2001). The diets were formulated to contain $19.4 \% \mathrm{CP}$ and $25.3 \%$ forage NDF concentrations. Throughout the experiment, cows were housed in tie stalls with continuous access to water. The experimental TMR was offered once daily $(0900 \mathrm{~h})$ at $110 \%$ of expected intake and cows were milked in their stalls twice daily (0600 and $1700 \mathrm{~h}$ ). Animals were allowed to exercise once daily (1100 h) for $2 \mathrm{~h}$.

\section{Data and Sample Collection}

Body weight was recorded on 2 consecutive days immediately prior to the start of the first period and on the last $2 \mathrm{~d}$ of each period. Body condition score was determined by 2 trained individuals at the beginning of the experiment and at the end of each period (a 5point scale was used, with $1=$ thin and $5=$ fat; Wildman 
et al., 1982). The amount of feed offered and orts were weighed and recorded daily during the collection period. Representative samples of all dietary ingredients, TMR, and orts (approximately $12.5 \%$, as-fed basis) were collected daily during the collection period. The orts were pooled and one sample was retained per cow per period. The DM content of barley silage and alfalfa hay was determined weekly to adjust dietary allocation of forages to maintain a consistent forage-to-concentrate ratio. Milk yield was measured daily and averaged over the 7-d collection period. Milk was sampled at every milking on d 19, 20, and 21 of each period and milk component concentrations (weighed by yield at each milking daily) and yields were averaged for these dates. Fecal and blood samples were collected from each cow on $\mathrm{d} 15$ to 21 every $28 \mathrm{~h}$ to account for diurnal variations ( $1100 \mathrm{~h}$ on d $15,1500 \mathrm{~h}$ on d $16,1900 \mathrm{~h}$ on d 17,2300 $\mathrm{h}$ on $\mathrm{d} 18,0300 \mathrm{~h}$ on $\mathrm{d} 20$, and $0700 \mathrm{~h}$ on d 21). Fecal samples $(150 \mathrm{~g})$ were collected from the rectum, frozen at $-20^{\circ} \mathrm{C}$, and composited into one sample per cow per period immediately prior to drying in a forced-air oven. Blood was sampled from the coccygeal vessels using Vacutainer tubes containing sodium heparin (Becton Dickinson, Franklin Lakes, NJ). Blood samples were immediately placed on ice and centrifuged within $1 \mathrm{~h}$ at $4^{\circ} \mathrm{C}$ for $30 \mathrm{~min}$ at $3,000 \times \mathrm{g}$. Plasma was harvested and stored at $-20^{\circ} \mathrm{C}$ until further analysis.

\section{Sample Analysis}

Diet ingredients, orts, and feces were dried in a $55^{\circ} \mathrm{C}$ forced-air oven for $72 \mathrm{~h}$ to determine DM concentration. The dried samples were ground through a 1-mm screen using a Wiley mill (Thomas-Wiley, Philadelphia, PA). Samples were analyzed for concentrations of DM, ash, $\mathrm{NDF}$, indigestible NDF, CP, ether extract (EE), and starch. Dry matter concentration was determined after drying samples at $135^{\circ} \mathrm{C}$ for $2 \mathrm{~h}$ (AOAC, 2002; method 930.15). Ash concentration was determined after $5 \mathrm{~h}$ at $550^{\circ} \mathrm{C}$ in a furnace (AOAC 2002; method 942.05). Neutral detergent fiber concentration was determined using amylase and sodium sulfite (Van Soest et al., 1991). Crude protein concentration was quantified by flash combustion with gas chromatography and thermal conductivity detection (Carlo Erba Instruments, Milan, Italy; Rhee et al., 2005). Starch was measured by an enzymatic method (Karkalas, 1985) after samples were gelatinized with sodium hydroxide, with glucose concentration measured using a glucose oxidase/peroxidase enzyme (No. P7119, Sigma, St. Louis, MO) and dianisidine dihydrochloride (No. F5803, Sigma). Absorbance was determined with a plate reader (SpectraMax 190, Molecular Devices Corp., Sunnyvale, CA). Ether extract concentration was determined using a
Goldfisch extraction apparatus (Labconco, Kansas City, MO; Wrolstad et al., 2005). Indigestible NDF was determined as NDF residue after 120-h incubation in the rumen, and was used as an internal marker to determine apparent total tract nutrient digestibility (Cochran et al., 1986).

The TMR and orts samples were analyzed for particle size distribution using a Penn State Forage Particle Separator (19.0-, 8.0-, and 1.18-mm sieves; Nasco, Fort Atkinson, WI) to determine the extent of sorting, which was expressed as a sorting index. The sorting index was calculated as the actual intake/expected intake for each portion retained on the individual screens. Expected intake was calculated as the particle size distribution of the TMR (\% as-fed basis) $\times$ actual as-fed intake. Actual intake was calculated as the amount of feed offered $\times$ particle size distribution in the TMR $(\%$ as-fed basis) - the amount feed refused $\times$ the particle size distribution in the orts samples (\%). A sorting index of 1 , less than 1 , and greater than 1 indicated no sorting, sorting against, and sorting for, respectively (Leonardi and Armentano, 2003).

Milk fat, protein, lactose, and SCC concentrations were measured with infrared spectroscopy by Edmonton-Alberta DHIA (MilkOScan 605, Foss Electric, Hillerød, Denmark), MUN was determined with an automated infrared Fossomatic 400 milk analyzer (Foss North America, Brampton, Ontario, Canada). Milk energy output was calculated according to the NRC (2001) using measured concentrations of milk fat, protein, and lactose. Commercial kits were used to determine plasma concentrations of insulin (Coat-A-Count, Diagnostic Products Corporation, Los Angeles, CA) and NEFA (NEFA C-kit, Wako Chemicals USA, Richmond, VA) using a previously described protocol modification (Johnson and Peters, 1993). Plasma glucose concentration was measured using a glucose oxidase/peroxidase enzyme and dianisidine dihydrochloride as described above.

\section{Statistical Analysis}

All data were analyzed using the fit model procedure of JMP (version 5.1, SAS Inc., Cary, NC) according to the following model:

$$
\mathrm{Y}_{\mathrm{ijkl}}=\mu+\mathrm{C}_{\mathrm{i}}+\mathrm{P}_{\mathrm{j}}+\mathrm{T}_{\mathrm{k}}+\mathrm{e}_{\mathrm{ijk} \mathrm{l}},
$$

where $\mu$ is the overall mean, $C_{i}$ is the random effect of cow ( $i=1$ to 31$), P_{j}$ is the fixed effect of period $(j=1$ to 3 ), $T_{k}$ is the fixed effect of treatment ( $k=1$ to 3 ), and $\mathrm{e}_{\mathrm{ijk}}$ is the residual, assumed to be normally distributed.

The parity $\times$ treatment interaction was originally included in the model, but it was later removed because 
Table 3. The DMI and performance of lactating dairy cows fed diets containing either a corn mixture $(\mathrm{CM})^{1}$ or steam-rolled barley, cultivar Dillon or cultivar Xena

\begin{tabular}{|c|c|c|c|c|c|c|}
\hline \multirow[b]{3}{*}{ Item } & \multirow[b]{3}{*}{$\mathrm{CM}$} & \multirow{2}{*}{\multicolumn{2}{|c|}{ Barley }} & \multirow[b]{3}{*}{$\mathrm{SE}$} & \multicolumn{2}{|c|}{$P$-value } \\
\hline & & & & & \multirow{2}{*}{$\begin{array}{l}\text { CM vs. } \\
\text { barley }\end{array}$} & \multirow{2}{*}{$\begin{array}{c}\text { Dillon } \\
\text { vs. Xena }\end{array}$} \\
\hline & & Dillon & Xena & & & \\
\hline DMI, kg/d & 23.6 & 21.4 & 21.8 & 0.7 & $<0.001$ & 0.35 \\
\hline \multicolumn{7}{|l|}{ Sorting index ${ }^{2}$} \\
\hline First (top) sieve, 19-mm & 1.03 & 0.96 & 0.93 & 0.03 & 0.02 & 0.46 \\
\hline Second sieve, $8-\mathrm{mm}$ & 0.96 & 1.02 & 1.03 & 0.02 & $<0.01$ & 0.51 \\
\hline Third sieve, $1.18-\mathrm{mm}$ & 1.02 & 1.02 & 1.01 & 0.01 & 0.65 & 0.45 \\
\hline Collection pan & 1.15 & 1.05 & 1.03 & 0.06 & 0.13 & 0.75 \\
\hline \multicolumn{7}{|l|}{ Yield, kg/d } \\
\hline Milk & 40.4 & 36.2 & 38.5 & 1.2 & $<0.01$ & 0.04 \\
\hline Milk fat & 1.33 & 1.26 & 1.23 & 0.06 & 0.10 & 0.55 \\
\hline Milk protein & 1.20 & 1.07 & 1.18 & 0.04 & $<0.001$ & $<0.001$ \\
\hline Milk lactose & 1.85 & 1.69 & 1.8 & 0.07 & $<0.01$ & $<0.01$ \\
\hline \multicolumn{7}{|l|}{ Milk composition, \% } \\
\hline Milk fat & 3.39 & 3.47 & 3.23 & 0.13 & 0.72 & 0.08 \\
\hline Milk protein & 2.99 & 2.89 & 3.08 & 0.06 & 0.85 & $<0.001$ \\
\hline Milk lactose & 4.65 & 4.49 & 4.62 & 0.06 & 0.06 & 0.03 \\
\hline $\mathrm{SCC}, 10^{3} / \mathrm{mL}$ & 147 & 331 & 229 & 114 & 0.21 & 0.78 \\
\hline MUN, mg/dL & 14.7 & 14.7 & 14.3 & 0.4 & 0.66 & 0.28 \\
\hline $4 \%$ FCM yield, $\mathrm{kg} / \mathrm{d}$ & 36.1 & 33.3 & 33.9 & 1.1 & $<0.01$ & 0.54 \\
\hline $\mathrm{NE}_{\mathrm{L}}$ milk output, ${ }^{3} \mathrm{Mcal} / \mathrm{d}$ & 26.5 & 23.6 & 24.8 & 0.8 & $<0.001$ & 0.12 \\
\hline Milk yield/DMI & 1.74 & 1.71 & 1.77 & 0.05 & 0.90 & 0.24 \\
\hline $\mathrm{NE}_{\mathrm{L}}$ milk output/NE intake $^{4}$ & 0.80 & 0.86 & 0.88 & 0.26 & 0.02 & 0.53 \\
\hline BW change, $\mathrm{kg} / \mathrm{d}$ & -0.23 & 0.12 & -0.53 & 0.12 & 0.87 & $<0.001$ \\
\hline BCS change, per $21 \mathrm{~d}$ & 0.02 & 0.01 & 0.06 & 0.03 & 0.63 & 0.24 \\
\hline
\end{tabular}

${ }^{1} \mathrm{CM}=$ corn mixture containing $87.5 \%$ dry ground corn, $11.4 \%$ beet pulp, and $1.1 \%$ urea (DM basis).

${ }^{2}$ Sorting index $=$ actual intake/expected intake $(<1$ sorting against, $>1$ sorting for, and =1 no sorting $)$

${ }^{3}$ Milk energy output was calculated from measured milk yield and concentrations of milk fat, protein, and lactose according to the $\mathrm{NRC}(2001): \mathrm{NE}_{\mathrm{L}}(\mathrm{Mcal} / \mathrm{kg})=0.0929 \times$ fat $\%+0.0547 \times \mathrm{CP} \%+0.0395 \times$ lactose $\%$.

${ }^{4} \mathrm{NE}_{\mathrm{L}}$ intake was calculated from $\mathrm{DMI}$ and measured $\mathrm{NE}_{\mathrm{L}}$ content of diets; digestible energy content of diets was first calculated from nutrient components actually digested in the total tract, and then converted to $\mathrm{NE}_{\mathrm{L}}$ according to the $\mathrm{NRC}(2001): \mathrm{ME}_{\mathrm{P}}(\mathrm{Mcal} / \mathrm{kg})=1.01 \times$ digestible energy $(\mathrm{Mcal} / \mathrm{kg})-0.45 ; \mathrm{NE}_{\mathrm{L}}(\mathrm{Mcal} /$ $\mathrm{kg})=\left[0.703 \times \mathrm{ME}_{\mathrm{P}}(\mathrm{Mcal} / \mathrm{kg})\right]-0.19$.

the interaction was not significant for all response variables. Orthogonal contrasts were made to evaluate the effect of CM vs. barley (mean of Dillon and Xena) and the effect of Dillon vs. Xena.

\section{RESULTS}

The diets contained about $39 \%$ barley grains or $40.6 \%$ $\mathrm{CM}$. Because the DM concentration of CM ingredient samples collected during the study was greater than expected, the diet actually contained slightly more CM than the $39 \%$ intended (DM basis; Table 2). The grain sources were added to the diet in approximately equal proportions; thus, the starch content of the diet was highest for CM, intermediate for Xena, and lowest for Dillon.

Cows fed CM had greater DMI compared with cows fed barley grain (23.6 vs. $21.6 \mathrm{~kg} / \mathrm{d}$; $P<0.001$; Table 3 ). Dry matter intake was not affected by the barley cultivar (21.8 vs. $21.4 \mathrm{~kg} / \mathrm{d} ; P=0.35)$. Cows fed CM sorted for longer particles (i.e., feed on the top sieve; $P=0.02$ ) and against medium-length particles on the second sieve $(P<0.01)$ of the particle size separator to a greater extent than cows fed barley. There were no differences in sorting between the barley treatments. Apparent total tract digestibility of DM ( 64.9 vs. $60.5 ; P<0.001$; Table 4 ), OM (69.7 vs. $65.7 \% ; P<0.001)$, starch (97.7 vs. $94.1 \% ; P<0.001$ ), and $\mathrm{EE}$ ( 83.3 vs. $77.6 \% ; P<0.001$ ) were higher for the CM treatment compared with barley grain treatments. Apparent total tract digestibility of starch was greater (95.6 vs. $92.6 \% ; P<0.001)$ and that of $\mathrm{EE}$ was lower (75.7 vs. $79.5 \% ; P<0.001)$ for Xena compared with Dillon. Apparent total tract digestibility of CP and NDF was not affected by treatment.

Daily yields of milk ( $40.4 \mathrm{vs} .37 .4 \mathrm{~kg} / \mathrm{d} ; P<0.01)$, milk protein $(1.20$ vs. $1.12 \mathrm{~kg} / \mathrm{d} ; P<0.001)$, and milk lactose (1.85 vs. $1.74 \mathrm{~kg} / \mathrm{d} ; P<0.01)$ were higher for cows fed CM than for cows fed barley grain. Milk fat yield (1.33 vs. $1.24 \mathrm{~kg} / \mathrm{d} ; P=0.10)$ and milk lactose concentration (4.65 vs. $4.55 \% ; P=0.06$ ) tended to be higher for cows fed CM diets compared with cows fed barley grain. Daily yields of milk ( $38.5 \mathrm{vs} .36 .2 \mathrm{~kg} / \mathrm{d} ; P=0.04)$, milk protein $(1.18$ vs. $1.07 \mathrm{~kg} / \mathrm{d} ; P<0.001)$, and lactose (1.80 vs. 1.69 $\mathrm{kg} / \mathrm{d} ; P<0.01)$ were higher for cows fed Xena compared 
Table 4. Apparent total tract nutrient digestibility of lactating dairy cows fed diets containing either a corn mixture $(\mathrm{CM})^{1}$ or steam-rolled barley, cultivar Dillon or cultivar Xena

\begin{tabular}{|c|c|c|c|c|c|c|}
\hline \multirow[b]{3}{*}{ Digestibility, \% } & \multirow[b]{3}{*}{$\mathrm{CM}$} & \multirow{2}{*}{\multicolumn{2}{|c|}{ Barley }} & \multirow[b]{3}{*}{$\mathrm{SE}$} & \multicolumn{2}{|c|}{$P$-value } \\
\hline & & & & & CM vs. & Dillon \\
\hline & & Dillon & Xena & & barley & vs. Xena \\
\hline $\mathrm{DM}$ & 64.9 & 60.1 & 60.8 & 0.8 & $<0.001$ & 0.52 \\
\hline $\mathrm{OM}$ & 69.7 & 65.5 & 66.0 & 0.7 & $<0.001$ & 0.61 \\
\hline Starch & 97.7 & 92.6 & 95.6 & 0.4 & $<0.001$ & $<0.001$ \\
\hline Ether extract & 83.3 & 79.5 & 75.7 & 0.7 & $<0.001$ & $<0.001$ \\
\hline $\mathrm{CP}$ & 68.2 & 67.8 & 66.7 & 0.7 & 0.32 & 0.34 \\
\hline NDF & 46.2 & 46.9 & 46.5 & 1.3 & 0.73 & 0.80 \\
\hline
\end{tabular}

${ }^{1} \mathrm{CM}=$ corn mixture containing $87.5 \%$ dry ground corn, $11.4 \%$ beet pulp, and $1.1 \%$ urea (DM basis).

with those fed Dillon. Concentrations of milk protein (3.08 vs. $2.89 \% ; P<0.001)$ and milk lactose $(4.62$ vs. $4.49 \% ; P=0.03)$ were also higher for Xena compared with Dillon. However, milk fat concentration tended to be higher (3.47 vs. 3.23\%; $P=0.08$ ) for cows fed Dillon than those fed Xena. The SCC and MUN were not affected by treatment.

Cows fed Dillon gained more BW (0.16 vs. $-0.53 \mathrm{~kg} /$ d) than cows fed Xena, although a treatment effect was not observed for the comparison between CM and barley grain treatments. The BCS was also not affected by treatment. Cows fed CM had a higher 4\% FCM yield (36.1 vs. $33.6 \mathrm{~kg} / \mathrm{d} ; P<0.01$ ) and milk energy output $(26.5$ vs. $24.2 \mathrm{Mcal} / \mathrm{d} ; P<0.001)$ compared with cows fed barley. Energy utilization efficiency, defined as net energy output of milk divided by net energy intake, was higher for barley compared with the CM treatment (86.9 vs. $80.1 \%$; $P=0.02$ ). Plasma concentrations of glucose and NEFA were not affected by treatment (Table 5). Plasma insulin concentration was higher for cows fed Xena than Dillon (8.50 vs. $5.91 \mu \mathrm{IU} / \mathrm{mL} ; P<0.01$ ), but no difference was observed between $\mathrm{CM}$ and barley grain treatments.

\section{DISCUSSION}

\section{Corn vs. Barley}

Replacing corn with barley reduced DMI of lactating dairy cows by about $2 \mathrm{~kg} / \mathrm{d}$. This reduction in DMI is similar to that reported in some studies (Casper and Schingoethe, 1989; McCarthy et al., 1989; Casper et al., 1990; Khorasani et al., 1994; Yang et al., 1997b), although other studies have not observed low intake among cows fed barley diets (De Peters and Taylor, 1985; Grings et al., 1992; Casper et al., 1999). Inconsistent effects of grain source on DMI can be attributed to the proportion of grain in the diet (DeVisser et al., 1990; Grings et al., 1992), the starch concentration of the diet (Tommervik and Waldern, 1969; Rode and Satter, 1988; DeVisser et al., 1990), and forage particle length (Rode and Satter, 1988). Diets containing higher concentrations of forage NDF promote chewing, salivation, and high rumen pH (Mertens, 1997), which mask some effects caused by differences in fermentability of diets in the rumen.

Milk yield was greater for cows fed CM although efficiency for milk production, defined either as milk yield/DMI or as $\mathrm{NE}_{\mathrm{L}}$ milk/ $/ \mathrm{NE}_{\mathrm{L}}$ intake, was not greater for the CM treatment. Thus, the higher milk yield of cows fed CM was attributed to greater DMI. Some previous research also reported a higher DMI and milk yield for corn-based diets compared with barley-based diets (McCarthy et al., 1989; Overton et al., 1995; Casper et al., 1999). However, other research observed no treatment effect on milk yield (Grings et al., 1992; Khorasani et al., 1994). The lack of effect of grain source on milk lactose, fat, and protein concentrations is consistent with some previous studies, but the effects of replacing

Table 5. Plasma metabolite concentrations of lactating dairy cows fed diets containing either a corn mixture $(\mathrm{CM})^{1}$ steam-rolled barley, cultivar Dillon or cultivar Xena

\begin{tabular}{|c|c|c|c|c|c|c|}
\hline \multirow[b]{3}{*}{ Plasma metabolite } & \multirow[b]{3}{*}{$\mathrm{CM}$} & \multirow{2}{*}{\multicolumn{2}{|c|}{ Barley }} & \multirow[b]{3}{*}{ SE } & \multicolumn{2}{|c|}{$P$-value } \\
\hline & & & & & CM ys & Dillon \\
\hline & & Dillon & Xena & & barley & vs. Xena \\
\hline NEFA, mEq/L & 102.0 & 120.7 & 104.4 & 8.0 & 0.32 & 0.24 \\
\hline Glucose, mg/dL & 61.3 & 60.3 & 61.1 & 0.7 & 0.32 & 0.24 \\
\hline Insulin, $\mu \mathrm{IU} / \mathrm{mL}$ & 7.44 & 5.91 & 8.50 & 0.64 & 0.64 & $<0.01$ \\
\hline
\end{tabular}

${ }^{1} \mathrm{CM}=$ corn mixture containing $87.5 \%$ dry ground corn, $11.4 \%$ beet pulp, and $1.1 \%$ urea (DM basis). 
corn with barley resulted in inconsistent effects on milk components. For example, Casper et al. (1990) reported that milk fat increased when corn replaced barley, but other research (De Peters and Taylor, 1985; Bilodeau et al., 1989; Casper and Schingoethe, 1989; McCarthy et al., 1989) found no differences in milk fat content. Milk lactose and protein concentrations were not different between barley- and corn-based diets in previous studies (De Peters and Taylor, 1985; Bilodeau et al., 1989; McCarthy et al., 1989; Grings et al., 1992).

\section{Effects of Barley Grain Treatments}

We used 2 barley cultivar lots, Dillon and Xena, to test our hypothesis that less ruminally fermentable barley grain would increase the productivity of dairy cows compared with more fermentable barley grain. The Xena barley used in this study had a greater starch concentration (58.7 vs. $50.0 \%$ of $\mathrm{DM}$ ) and greater in vitro 6-h starch digestibility (78.0 vs. $73.5 \%$ ) compared with Dillon barley. Although actual ruminal starch digestion was not determined in this study, the higher plasma insulin concentration ( 8.50 vs. $5.91 \mu \mathrm{IU} / \mathrm{mL}$ ) and apparent total tract starch digestibility (95.6 vs. 92.6\%) for cows fed Xena compared with Dillon were consistent with the expected greater ruminal starch digestion for Xena compared with Dillon. Furthermore, a companion study conducted with the same lots of Xena and Dillon found that ruminally cannulated dairy cows fed Xena had greater propionate concentration in ruminal fluid and a longer time that rumen $\mathrm{pH}$ was below 5.8 compared with cows fed Dillon (Silveira et al., 2007).

We expected less reduction in feed intake for cows fed Dillon compared with Xena because of the slower ruminal fermentation of Dillon. Contrary to expectations, DMI was not different between Xena and Dillon. Our findings are in agreement with Yang et al. (1997a), who compared hull-less barley with hulled barley and corn grain. They reported that DMI was reduced by 1.3 $\mathrm{kg} / \mathrm{d}$ for cows fed barley compared with corn grain, but they did not observe a difference in DMI between barley grain treatments although hull-less barley was more slowly digested in the rumen than hulled barley (Yang et al., 1997a). Excess fermentation in the rumen is generally considered as the primary cause of lower DMI and milk yield for cows fed barley grains compared with corn grain (McCarthy et al., 1989; Overton et al., 1995). Ruminal concentration of propionate is typically higher for barley-based diets than corn-based diets (McCarthy et al., 1989; Overton et al., 1995), which is consistent with the hypophagic effect of propionate in ruminant animals (Allen, 2000) and decreases energy intake (Oba and Allen, 2003). However, barley grains that are less fermentable in the rumen did not prevent a reduction in DMI in the study of Yang et al. (1997b) nor in our study, which indicates that the lower DMI often observed for cows fed barley grains compared with corn grains cannot be solely attributed to excess fermentation or hypophagic effects of propionate.

Because DMI was not different between Xena and Dillon, the greater milk yield of cows fed Xena compared with Dillon is attributed to the higher starch content of the Xena diet coupled with its higher total tract starch digestibility. Cows fed Xena tended to have a lower milk fat concentration, which is consistent with the expected greater starch digestion in the rumen for the Xena treatment. As rumen $\mathrm{pH}$ declines, the biohydrogenation of unsaturated fatty acids is disrupted, increasing the accumulation of trans-18:1, which depresses de novo fatty acid synthesis in the mammary gland (Griinari et al., 1998). Greater milk protein concentration for the Xena treatment can be attributed to the expected greater ruminal starch digestion. The higher propionate concentration in ruminal fluid from cows fed Xena (Silveira et al., 2007) would have favored the use of propionate by the liver for gluconeogenesis to a greater extent than for cows fed Xena. Increased gluconeogenesis has a sparing effect on AA, increasing the availability of AA for milk protein synthesis in the mammary gland. Greater milk protein concentration for cows fed Xena compared with those fed Dillon can be also attributed to the greater plasma insulin concentration (Mackle et al., 1999).

The effects of barley grain cultivar on animal productivity have been studied for beef cattle. Bradshaw et al. (1996) fed 2 barley cultivars with the same test weight $(67 \mathrm{~kg} / \mathrm{hL})$, Steptoe and Klages, to growing steers (31\% barley in the diet) and finishing steers $(87 \%$ barley in the diet) and found no differences in steer performance. However, when 6 studies were performed over $5 \mathrm{yr}$, Klages increased weight gain in one study, decreased weight gain in 2 studies, and resulted in no difference in gain in the remaining 3 studies (Kercher et al., 1986). Ovenell-Roy et al. (1998a,b) fed 6 barley cultivars to steers in finishing diets and found that digestibility of NDF was the main factor contributing to cultivar differences, where the cultivar with the lowest NDF digestibility tended to have lower starch and digestible energy contents. Covered (Leduc, $61.9 \mathrm{~kg} / \mathrm{hL}$ ) and hull-less (Condor, $76.1 \mathrm{~kg} / \mathrm{hL}$ ) barley was fed to steers in finishing diets (77\% barley in the diet) and gain was found to be similar for both cultivars; however, cattle fed Leduc had higher intake, leading to decreased feed efficiency and dietary energy density (Zinn et al., 1996). A study evaluating 3 cultivars, Gunhilde (2-row, $64.5 \mathrm{~kg} / \mathrm{hL}$ ), Harrington (2-row malting, $63.1 \mathrm{~kg} / \mathrm{hL}$ ), and Medallion (6-row, $61.9 \mathrm{~kg} / \mathrm{hL}$ ), concluded that Me- 
dallion had the better feed conversion when fed to steers in finishing diets ( $80 \%$ barley in the diet), followed by Gunhilde and Harrington (Boss and Bowman, 1996).

The effects of barley grain differing in nutrient composition were studied to some extent using lactating dairy cows (Yang et al., 1997a,b; Foley et al., 2006), but most research evaluating barley grain using dairy cows has compared the feeding value of barley grain with that of corn grain, overlooking the variation within barley grain. We found significant differences in milk protein concentration and plasma insulin concentration between barley grain treatments, but not between CM and barley treatments. These observations indicate that selection of barley grain can affect some nutrient metabolism and milk production responses to a greater extent than selection of grain type (i.e., corn vs. barley). Selection of barley cultivar can be a viable management option to enhance the productivity of dairy cows, but our research data need to be interpreted with caution. Although we found greater milk yield for cows fed Xena compared with those fed Dillon, it cannot be concluded that Xena is a better cultivar than Dillon for lactating dairy cows. Effects of the growing environment and interactions of barley genetics with its growing environment are expected to greatly affect the physical and chemical characteristics of barley grains. In the current study, Xena was compared with Dillon, but it is not known whether the lots of grain used in this study are representative of each cultivar. However, our study clearly demonstrates that selection of barley grain can affect the productivity of lactating dairy cows. Further research is warranted to identify the quality traits of barley grain that influence the productivity of lactating dairy cows.

\section{CONCLUSIONS}

Cows fed corn had higher DMI and milk production compared with those fed barley grain. However, despite expected lower ruminal starch digestion caused by lower starch content and reduced fermentability, cows fed Dillon had similar DMI as cows fed Xena. Milk yield and milk protein concentration were lower for cows fed Dillon compared with cows fed Xena, indicating that reducing the ruminal starch digestion of barley grain may not improve the productivity of lactating dairy cows. Barley grain fed to ruminants needs to be carefully selected because of large variations in nutrient composition and digestibility across the lots and their effects on productivity of lactating dairy cows. Future research needs to identify the quality traits of barley grain that affect the productivity of animals.

\section{ACKNOWLEDGMENTS}

The authors wish to acknowledge the Alberta Livestock Industry Development Fund (Edmonton, Alberta, Canada) and Alberta Milk (Edmonton, Alberta, Canada) for their financial support of this research project. The authors also thank G. McGregor, A. Toma, and C. Wiebe-Buchanan for their assistance in sample collection, and K. Gill, M. Owen, L. Manson, and J. Bilobrowka for their assistance in sample analysis. We also thank the staff at the Dairy Research and Technology Centre for animal care.

\section{REFERENCES}

Aldrich, J. M., L. D. Muller, G. A. Varga, and L. C. Griel, Jr. 1993. Nonstructural carbohydrate and protein effects on rumen fermentation, nutrient flow, and performance of dairy cows. J. Dairy Sci. 76:1091-1105.

Allen, M. S. 2000. Effects of diet on short-term regulation of feed intake by lactating dairy cattle. J. Dairy Sci. 83:1598-1624.

AOAC (Association of Official Analytical Chemists). 2002. Official Methods of Analysis. 17th ed., Vol. 1, Revision 1. AOAC, Arlington, VA.

Bilodeau, P. P., D. Petitclerc, N. St. Pierre, G. Pelletier, and G. J. St. Laurent. 1989. Effects of photoperiod and pair-feeding on lactation of cows fed corn or barley grain in total mixed rations. J. Dairy Sci. 72:2999-3005.

Boss, D. L., and J. G. Bowman. 1996. Barley varieties for finishing steers: I. Feedlot performance, in vivo diet digestion, and carcass characteristics. J. Anim. Sci. 74:1967-1972.

Bradshaw, W. L., D. D. Hinman, R. C. Bull, D. O. Everson, and S. J. Sorensen. 1996. Effects of barley variety and processing methods on feedlot steer performance and carcass characteristics. J. Anim. Sci. 74:18-24.

Casper, D. P., H. A. Maiga, M. J. Brouk, and D. J. Schingoethe. 1999. Synchronization of carbohydrate and protein sources on fermentation and passage rates in dairy cows. J. Dairy Sci. 82:1779-1790.

Casper, D. P., and D. J. Schingoethe. 1989. Lactational response of dairy cows to diets varying in ruminal solubilities of carbohydrates and crude protein. J. Dairy Sci. 72:928-941.

Casper, D. P., D. J. Schingoethe, and W. A. Eisenbeisz. 1990. Response of early lactation dairy cows fed diets varying in source of nonstructural carbohydrate and crude protein. J. Dairy Sci. 73:1039-1050.

Cochran, R. C., D. C. Adams, J. D. Wallace, and M. L. Galyean. 1986. Predicting digestibility of different diets with internal markers: Evaluation of four potential markers. J. Anim. Sci. 63:1476-1483.

De Peters, E. J., and S. J. Taylor. 1985. Effects of feeding corn or barley on composition of milk and diet digestibility. J. Dairy Sci. 68:2027-2032.

DeVisser, H., P. L. Van Der Togt, and S. Tamminga. 1990. Structural and non-structural carbohydrates in concentrate supplements of silage-based dairy cow rations: 1 . Feed intake and milk production. Neth. J. Agric. Sci. 38:487-498.

Foley, A. E., A. N. Hristov, A. Melgar, J. K. Ropp, R. P. Etter, S. Zaman, C. W. Hunt, K. Huber, and W. J. Price. 2006. Effect of barley and its amylopectin content on ruminal fermentation and nitrogen utilization in lactating dairy cows. J. Dairy Sci. 89:4321-4335.

Griinari, J. M., D. A. Dwyer, M. A. McGuire, D. E. Bauman, D. L. Palmquist, and K. V. V. Nurmela. 1998. Trans-octadecenoic acids and milk fat depression in lactating dairy cows. J. Dairy Sci. 81:1251-1261.

Grings, E. E., R. E. Roffler, and D. P. Deitelhoff. 1992. Evaluation of corn and barley as energy sources for cows in early lactation fed alfalfa-based diets. J. Dairy Sci. 75:193-200. 
Johnson, M. M., and J. P. Peters. 1993. Technical note: An improved method to quantify nonesterified fatty acids in bovine plasma. J. Anim. Sci. 71:753-756.

Karkalas, J. 1985. An improved enzymatic method for the determination of native and modified starch. J. Sci. Food Agric. 36:10191027.

Kercher, C. J., D. Bergener, and R. Jones. 1986. Barley varieties, high moisture corn, vs. dry corn and single or multiple hormone implants for finishing beef steers. Pages 3-8 in Wyoming Agric. Exp. Stn. Bull., Wyoming Agric. Exp. Stn., Laramie.

Khorasani, G. R., G. De Boer, B. Robinson, and J. J. Kennelly. 1994. Influence of dietary protein and starch on production and metabolic responses of dairy cows. J. Dairy Sci. 77:813-824.

Khorasani, G. R., J. Helm, and J. J. Kennelly. 2000. In situ rumen degradation characteristics of sixty cultivars of barley grain. Can. J. Anim. Sci. 80:691-701.

LaFrance, J. T., and M. J. Watts. 1986. The value of protein in feed barley for beef, dairy and swine feeding. West J. Ag. Econ. 11:76-81.

Leonardi, C., and L. E. Armentano. 2003. Effect of quantity, quality, and length of alfalfa hay on selective consumption by dairy cows. J. Dairy Sci. 86:557-564.

Mackle, T. R., D. A. Dwyer, K. L. Ingvartsen, P. Y. Chouinard, J. M. Lynch, D. M. Barbano, and D. E. Bauman. 1999. Effects of insulin and amino acids on milk protein concentration and yield from dairy cows. J. Dairy Sci. 82:1512-1524.

McCarthy, R. D., Jr., T. H. Klusmeyer, J. L. Vicini, and J. H. Clark. 1989. Effects of source of protein and carbohydrates on ruminal fermentation and passage of nutrients to the small intestine of lactating cows. J. Dairy Sci. 72:2002-2016.

Mertens, D. R. 1997. Creating a system for meeting the fiber requirements of dairy cows. J. Dairy Sci. 80:1463-1481.

Mitzner, K. C., F. G. Owen, and R. J. Grant. 1994. Comparison of sorghum and corn grains in early and midlactation diets for dairy cows. J. Dairy Sci. 77:1044-1051.

Nocek, J. E., and S. Tamminga. 1991. Site of digestion of starch in the gastrointestinal tract of dairy cows and its effect on milk yield and composition. J. Dairy Sci. 74:3598-3629.

NRC. 2001. Nutrient Requirements of Dairy Cattle. 7th ed. National Academy Press, Washington, DC.

Oba, M., and M. S. Allen. 2003. Intraruminal infusion of propionate alters feeding behavior and decreases energy intake of lactating dairy cows. J. Nutr. 133:1094-1099.

Ovenell-Roy, K. H., M. L. Nelson, J. A. Froseth, and S. M. Parish. 1998a. Variation in chemical composition and nutritional quality among barley cultivar for ruminants. 2. Digestion, ruminal characteristics and in situ disappearance kinetics. Can. J. Anim. Sci. 78:377-387.

Ovenell-Roy, K. H., M. L. Nelson, J. A. Froseth, S. M. Parish, and E. L. Martin. 1998b. Variation in chemical composition and nutri- tional quality among barley cultivars for ruminants. 1. Steer finishing performance, diet digestibilities and carcass characteristics. Can. J. Anim. Sci. 78:369-376.

Overton, T. R., M. R. Cameron, J. P. Elliottt, J. H. Clark, and D. R. Nelson. 1995. Ruminal fermentation and passage of nutrients to the duodenum of lactating cows fed mixture of corn and barley. J. Dairy Sci. 78:1981-1998.

Rhee, K. C. 2005. Determination of total nitrogen. Pages 105-113 in Handbook of Food Analytical Chemistry: Water, Proteins, Enzymes, Lipids, and Carbohydrates. R. E. Wrolstad, ed. John Wiley and Sons, Hoboken, NJ.

Robinson, P. H., and J. J. Kennelly. 1989. Influence of ammoniation of high moisture barley on its in situ rumen degradation and influence on rumen fermentation in dairy cows. Can. J. Anim. Sci. 68:839-851.

Rode, L. M., and L. D. Satter. 1988. Effect of amount and length of alfalfa hay in diets containing barley or corn on site of digestion and rumen microbial protein synthesis in dairy cows. Can. J. Anim. Sci. 68:445-454.

Silveira, C., M. Oba, W. Z. Yang, and K. A. Beauchemin. 2007. Selection of barley grain affects ruminal fermentation, starch digestibility, and productivity of lactating dairy cows. J. Dairy Sci. 90:2860-2869.

Tommervik, R. S., and D. E. Waldern. 1969. Comparative feeding value of wheat, corn, barley, milo, oats and a mixed concentrate ration for lactating cows. J. Dairy Sci. 52:68-73.

Van Soest, P. J., J. B. Robertson, and B. A. Lewis. 1991. Methods for dietary fiber, neutral detergent fiber, and nonstarch polysaccharides in relation to animal nutrition. J. Dairy Sci. 74:35833597.

Wildman, E. E., G. M. Jones, P. E. Wagner, R. L. Boman, H. F. Troutt Jr., and T. N. Lesch. 1982. A dairy cow body condition scoring system and its relationship to selected production characteristics. J. Dairy Sci. 65:495-501.

Yang, W. Z., K. A. Beauchemin, B. I. Farr, and L. M. Rode. 1997a Comparison of barley, hull-less barley, and corn in the concentrate of dairy cows. J. Dairy Sci. 80:2885-2895.

Yang, W. Z., K. A. Beauchemin, K. M. Koenig, and L. M. Rode. 1997b. Comparison of hull-less barley, barley, or corn for lactating cows: Effects on extent of digestion and milk production. J. Dairy Sci. 80:2475-2486.

Yu, P., D. A. Christensen, C. R. Christensen, M. D. Drew, B. G. Rossnagel, and J. J. McKinnon. 2004. Use of synchrotron FTIR microspectroscopy to identify chemical differences in barley endosperm tissue in relation to rumen degradation characteristics. Can. J. Anim. Sci. 84:523-527.

Zinn, R. A., M. Montano, and Y. Shen. 1996. Comparative feeding value of hull-less vs. covered barley for feedlot cattle. J. Anim. Sci. 74:1187-1193. 